\title{
Fund Manager Duality: \\ Impact on Performance and Investment Behavior
}

\author{
Alexander Kempf, Alexander Puetz, and Florian Sonnenburg*
}

August 2012

\begin{abstract}
Agency conflicts can arise when a fund manager also chairs the board of the fund. We examine the consequences of this fund manager duality using a broad sample of single managed US equity funds. We find that duality managers significantly underperform non-duality managers. This underperformance results from duality funds in the bottom performance quintile. This suggests that duality managers can avoid being laid off despite their bad performance. Consistent with this lower risk of dismissal, duality managers follow more risky investment strategies. They choose more unsystematic risk and follow more extreme investment styles which lead to more extreme performance outcomes. Only about one fifth of the nonduality managers invest as extremely as the average duality manager. However, all these consequences of manager duality can be cured by hiring independent directors.
\end{abstract}

JEL classification: G23, G34

EFM classification: 110, 150, 370, 380

Keywords: Fund manager duality, Fund governance, Agency conflicts, Mutual funds

\footnotetext{
* All authors are from Department of Finance and Centre for Financial Research (CFR), University of Cologne, Germany. Email: kempf@wiso.uni-koeln.de, puetz@wiso.uni-koeln.de, and sonnenburg@wiso.uni-koeln.de. Adress: Albertus Magnus Platz, 50923 Cologne. Phone: +49 221470 2714. Fax: +49 2214703992.
} 


\section{Introduction}

Agency problems are imminent when the decision makers do not bear the wealth effects of their decisions. Therefore, companies typically separate decision making from decision control. The board of directors' role is to control the decisions of the managers and as the last resort - to fire poorly performing managers (see, e.g., Fama and Jensen (1983)). A natural conflict of interest arises if a manager is also member of the board of directors and, thus, controlling herself. This problem is particularly severe if the CEO of a company is also chairing the board of the company often leading to poor company performance (see, e.g., Rechner and Dalton (1991)) and making it difficult for the board to remove poorly performing managers (see, e.g., Goyal and Park (2002)).

In this paper we analyze the consequences of manager duality in the US mutual fund industry. In particular, we focus on single managed funds where the fund manager also serves as the chairman of the fund board. ${ }^{1}$ In this case, the fund manager has the maximum managerial flexibility: She decides on the investments of the fund and, at the same time, chairs the board controlling and potentially replacing her. We hypothesize that this reduced level of control and replacement risk has three main consequences. (i) Duality managers use their flexibility in their own interest, e.g., by spending less effort to their work, and eventually deliver a worse performance than non-duality managers. (ii) Duality managers are aware of the lack of replacement risk and follow more risky investment strategies than non-duality managers. This strategy is highly sensible since it allows them to benefit from the welldocumented asymmetric performance-flow relation (see, e.g., Chevalier and Ellison (1997)) without bearing the replacement risk if their investment bets are not successful. (iii) The flexibility of the duality managers is the higher, the less effective the other members of the board perform their governance function. Therefore, we hypothesize that the effects of

\footnotetext{
${ }^{1}$ For an overview on the role of a mutual fund's board see Cremers, Driessen, Maenhout, and Weinbaum (2009) or http://www.ici.org/idc/policy/governance/faq_fund_gov_idc.
} 
manager duality on performance and risk-taking are stronger if there are less independent members on the board of directors and if these members invest less money into the fund.

Testing these hypotheses using data on fund managers offers a big advantage over using data on CEOs: The decisions of fund managers are easily observed since they are directly reflected in fund returns. In contrast, the decisions of CEOs do not directly translate into company performance, but have to be implemented by the employees of the company. Thus, it is harder to extract the CEO decisions from the company performance.

Our empirical results strongly support the hypotheses stated above. We find that funds run by duality managers (duality funds) significantly underperform funds run by non-duality managers (non-duality funds). The difference in performance (measured as objective-adjusted return, Jensen one-factor alpha, Fama-French three-factor alpha, or Carhart four-factor alpha) is about two percent per year even after controlling for fund and manager characteristics. The significantly higher total expense ratios of the duality funds (1.7 percent versus 1.26 percent) cannot explain the performance difference. Based on gross returns, the duality funds still underperform the non-duality funds by about 1.5 percent per year. This suggests that manager duality hurts investors in two ways: Duality managers not only make worse investment decisions but also charge higher fees. Stratifying the funds into quintiles by their performance shows that the overall performance difference results from the very poor performance of the duality funds in the bottom quintile. We not only find that an above-average fraction of duality managers is in the bottom quintile, but also find that the average performance of duality funds in the bottom quintile is about three percent smaller than the average performance of non-duality funds in the bottom quintile. This result is consistent with the view that duality managers are not replaced even if they deliver a poor performance. Indeed, we do not find a single replacement of duality managers in our sample period 2005 - 2009 . 
Given the lack of replacement risk, one expects that duality managers are willing to follow more risky investment strategies to exploit the asymmetric performance-flow relation. In particular, we expect them to take more unsystematic risk (see, e.g., Chevalier and Ellison (1999)), follow more extreme investment styles, and consequently deliver more extreme performance outcomes. Our empirical study provides strong support for these hypotheses. No matter which market model we use and whether we look at net or gross returns, we get the following results: First, the unsystematic risk of duality funds is about one quarter higher than the unsystematic risk of non-duality funds. This risk difference is highly significant. Second, duality funds follow much more extreme investment styles than non-duality funds. Using the style extremity measure developed in Bär, Kempf, and Ruenzi (2011), we find the extremity of duality funds is significant larger than the style extremity of non-duality funds. The overall extremity measure, which by definition equals one for the average manager, is about 1.3 for the duality managers whereas the respective number for the non-duality manager is only 0.95 . This implies that only 21 percent of the non-duality managers invest as extremely as the average duality manager. Third, duality funds deliver much more extreme performance outcomes than non-duality funds. Based on the performance extremity measure of Bär, Kempf, and Ruenzi (2011), we find values between 1.33 (based on Jensen alpha) and 1.45 (based on Fama-French alpha) for duality managers which are significantly larger than the value obtained for non-duality managers. The latter are within the narrow range from 0.93 to 0.95. Putting it differently, less than one quarter of the non-duality managers delivers a performance which is as extreme as the performance of the average duality manager.

Overall, our results lead us to conclude that fund investors not only get a worse average performance when choosing a duality fund, but also get a more extreme performance. Therefore, a risk-averse fund investor is, in general, better off avoiding duality funds. This finding leads us to the final question addressed in the paper: Can the negative consequences of manager duality be mitigated by appointing independent board members? The answer is 
yes and, thus, supports our main hypothesis (iii). We show that the performance and the risktaking effect of manager duality is the smaller the more independent members in the board are and the more money the independent members of the board have invested in the fund. This result is highly sensible since these independent board members have a strong incentive to oversee the fund in which they are invested and to limit the flexibility of the duality manager. Therefore, they reduce the agency conflicts arising from managers' duality. For example, the performance handicap of duality funds disappears if six independent managers are on the board or if the average independent director invests around 65,000 USD in the fund.

Our paper contributes to two strands of the literature. First, it is related to the corporate finance literature which examines the impact of CEO duality on firm performance (see, e.g., Adams, Almeida, and Ferreira (2005), Brickley, Coles, and Jarrell (1997), or Rechner and Dalton (1991)). Our study contributes to this literature in two ways. To begin with we are the first who look at the impact of manager duality on performance in the mutual fund industry. Looking at the fund industry allows for a cleaner calculation of the impact of the manager's decision since her decision is directly reflected in fund returns. Our second contribution to this literature is that our paper is, to our knowledge, the first one which looks at the consequences of reduced replacement risk on the behavior of duality managers in general.

Second, our paper is related to the growing literature on mutual fund governance which highlights the importance of independent board members for manager replacement and fund performance. Examples are Fu and Wedge (2011), Ding and Wermers (2009), Ferris and Yan (2007), Khorana, Tufano, and Wedge (2007), U.S. Securities and Exchange Commission (2005), and Tufano and Sevick (1997). We differ from these papers by analyzing the impact of manager duality on fund performance and manager behavior and by showing how independent board members can cure the duality effect. 
The remainder of this paper is organized as follows. In Section 2, we describe the data and provide fund and manager characteristics for duality and non-duality funds. In Section 3, we test our first main hypothesis by analyzing performance differences between both groups. Section 4 is dedicated to tests of our second main hypothesis. There we analyze differences in investment behavior between duality and non-duality managers. In Section 5, we test our third hypothesis by studying whether the impact of manager duality on performance and investment behavior is weakened by independent board members. Section 6 concludes.

\section{Data}

For our empirical analysis, we use data from three sources: (1) the Center for Research in Security Prices (CSRP) Survivor-Bias Free US Mutual Fund Database ${ }^{2}$, (2) Morningstar Principia and (3) mutual funds' Statement of Additional Information (SAI) filed with the SEC. Our data cover the period 2005-2009.

From the CRSP Survivor-Bias Free Mutual Fund Database we gather information on mutual funds' monthly returns, total net assets, and other fund characteristics. We focus on actively managed, domestic equity funds and exclude bond funds and international funds as well as index funds. We use the Lipper objective code to define a fund's investment objective. We aggregate the Lipper segments into seven broad categories: Aggressive Growth, Growth and Income, Income, Growth, Sector Funds, Utility Funds, and Mid-Cap Funds. Many funds offer multiple share classes which are listed as separate entries in the CRSP database. As these share classes are backed up by the same portfolio, we aggregate all share classes at the fund level to avoid multiple counting. We concentrate on single managed funds since we

\footnotetext{
${ }^{2}$ Source: CRSP, Center for Research in Security Prices. Graduate School of Business, The University of Chicago. Used with permission. All rights reserved.
} 
conjecture that the duality effect is most pronounced if the manager has the full power of making the investment decisions.

We match the CRSP funds to the funds in the Morningstar Principia Database using fund ticker, fund name, and manager name. The Morningstar database provides detailed information on managers’ biography that includes data on managers’ educational background, e.g., whether a manager holds an MBA, a PhD, or a Chartered Financial Analysts (CFA) designation and the date that a manager was first assigned to a fund. We calculate the managers' industry tenure as the number of years since the year that Morningstar reports for a manager to be the first year managing a fund in the Morningstar database.

The third data source is the mutual funds' SAI (in SEC filings 485APOS and 485BPOS), which are Part B of the mutual funds’ prospectus. It includes detailed information on each board member. The data from the SEC filings 485APOS and 485BPOS can be downloaded in text files from SEC EDGAR. We match these files with the CRSP data using the fund's name, also accounting for the fact that the fund name often differs from the filer name under which a mutual fund discloses its filings with the SEC or that the filings 485APOS and 485BPOS may contain SAI from multiple funds. For each fund we manually collect the following board information from the SEC files: Name of director, whether the director is interested or independent as defined in the Investment Company Act (ICA), and the directors' ownership in the fund. The ownership is reported in five ranges: None; \$1$\$ 10,000 ; \$ 10,001-\$ 50,000 ; \$ 50,001-\$ 100,000$ or over $\$ 100,000$.

Our final sample consists of 1,894 fund year observations. Table 1 reports summary statistics for the number of funds in the sample, funds' total net assets (TNA), expense ratio, funds’ age, and turnover ratio.

- Please insert TABLE 1 approximately here - 
Overall, our sample covers a total of 636 distinct funds. The average fund size is around 1.7 billion USD with only one break down in the subprime crisis. The average expense ratio in our sample decreases from 1.45 percent in 2005 to 1.24 percent in 2009. The average fund in our sample exists for about 17 years and turns over about 92 percent of its portfolio per year. Over the sample period, the turnover ratio increases from 85 percent to 101 percent.

In Table 2 we show fund and manager characteristics for duality and non-duality funds.

- Please insert TABLE 2 approximately here -

In about 14 percent of all funds, the manager also acts as chairman of the fund's board. These funds are only about half the size of the non-duality funds and their expense ratios are significantly higher. ${ }^{3}$ Regarding management fee, fund's age, and fund's turnover, we do not find a significant difference between duality and non-duality funds.

When looking at the characteristics of duality managers we find that almost all of them are male managers. The percentage (99 percent) is much higher than the percentage of male managers in non-duality funds (91 percent). Furthermore, duality managers differ from nonduality managers with respect to their education and experience: Duality managers hold an MBA degree more often and have more industry experience.

\footnotetext{
${ }^{3}$ This offers a first indication that the governance mechanisms of duality funds might be weaker than those of non-duality funds since a lower expense ratio is typically used as a proxy for better fund governance. See, e.g., Cremers, Driessen, Maenhout, and Weinbaum (2009), Del Guercio, Dann, and Partch (2003), and Tufano and Sevick (1997) for a discussion on the negative relation between fund fees and governance.
} 


\section{Performance Level}

\subsection{Overall}

In this section we test our hypothesis (i): Duality funds perform worse than nonduality funds. We use four different performance measures: (1) excess return over the average return in the fund's market segment (objective-adjusted returns), (2) Jensen (1968) one-factor alpha, (3) Fama and French (1993) three-factor alpha, and (4) Carhart (1997) four-factor alpha. ${ }^{4}$ We calculate the performance measures based on net returns and gross returns. To calculate a fund's gross returns, we divide a fund's yearly expense ratio by twelve and add it to the fund's monthly net return observations. Whereas net returns reflect the investment result from the view of the fund investor, gross returns better measure the quality of the investment decisions of the fund manager.

We conduct multivariate regressions and use the annualized performance measures as dependent variable in these regressions. Our main independent variable is the Duality dummy which equals one if the fund's manager also serves as chairman on the fund's board of directors in the respective year and zero otherwise. We add further variables to control for fund and manager characteristics. At the fund level, we use the logarithm of the fund's lagged size, the fund's yearly turnover ratio, and the fund's age as control variables to the regression. At the manager level, we control for the manager’s educational degrees (dummy variables for an MBA, a CFA, and a PhD) and for the manager's industry tenure. To control for any unobservable time or segment effects that could equally affect all funds in a given year or a particular market segment, respectively, we also include time and segment fixed effects in the regressions where appropriate. Panel A of Table 3 presents results using performance measures based on net returns, Panel B based on gross returns.

\footnotetext{
${ }^{4}$ The latter three alpha measures are determined based on a yearly estimation of the respective factor models. The factor-mimicking portfolio returns for the respective factors and the risk-free rate were taken from Kenneth French's website, http://mba.tuck.dartmouth.edu/pages/faculty/ken.french/data_library.html.
} 
The results support our hypothesis (i): duality funds achieve significantly worse performance compared to non-duality funds. The net performance differs by about two percent p.a. even after controlling for fund and manager characteristics. Based on gross returns, the duality funds still underperform by about 1.5 percent per year. ${ }^{5}$ Thus, we conclude that fund investors suffer from manager duality in two ways: duality managers make poor investment decisions and charge higher fees so that the underperformance for the investors is even worse. Regarding the control variables, we find a negative influence of fund size and turnover on performance. ${ }^{6}$ Furthermore, a fund's age and a manager's MBA degree have a slightly positive impact in some specifications. ${ }^{7}$

\subsection{Stratified by Performance Quintiles}

In this section, we examine a potential reason for the observed underperformance. As documented in the corporate literature, duality managers face a significantly lower risk of dismissal (see, e.g., Goyal and Park (2002), Cannella and Lubatkin (1993)). Based on this rationale, we expect that poorly performing duality managers tend to stay with their fund whereas poorly performing non-duality managers are fired. Therefore, we expect to see more poorly performing managers in duality funds. To test this conjecture, we sort all funds into five equal sized groups according to their performance in the respective year. Then, we calculate the percentage of duality funds and the percentage of non-duality funds in each performance quintile.

\footnotetext{
${ }^{5}$ As a robustness check, we also verify our results using a portfolio approach as in Carhart (1997). We form two portfolios which consist of duality and non-duality funds, respectively, and compare these portfolios' time series of monthly returns. Results (not reported) remain qualitatively the same.

${ }^{6}$ See, e.g., Chen, Hong, Ming, and Kubik (2004), Berk and Green (2004), and Carhart (1997).

${ }^{7}$ The positive impact of an MBA degree is broadly consistent with the findings of, e.g., Golec (1996) and Gottesman and Morey (2006).
} 
The results clearly indicate an above-average fraction of duality managers in the bottom quintile. Between 27 percent and 33 percent of all duality funds are in the lowest performance quintile. This fraction is significantly higher (at the $1 \%$ level) than the expected fraction of 20 percent for all performance measures, based on an unreported binomial test.

Next we compare the average performance between duality funds and non-duality funds in each performance quintile using the four performance measures introduced in Section 3.1. For the sake of brevity, we only report the results based on gross returns in Table 4. The results based on net returns are qualitatively the same.

- Please insert TABLE 4 approximately here -

The results show that the performance difference between duality and non-duality funds emerges from poorly performing funds. The performance difference between duality and non-duality funds is the largest in the bottom quintile, no matter which performance measure we use. It is significant at the 5\%-level, at least. For example, duality funds in the bottom quintile underperform non-duality peers by about 3.3 percent p.a. based on Carhart (1997) four-factor alpha. The performance differences in the other quintiles are almost always insignificant.

To check this finding we run multivariate regressions using the same control variables as in Section 3.1. In Panels A-E of Table 5, we use subsamples of the funds in each quintile and regress their annual performance measures on the duality dummy and the control variables.

- Please insert TABLE 5 approximately here -

The regression results confirm our previous findings: In the bottom quintile (Panel E) duality funds underperform non-duality funds remarkably. The difference is significant in a statistical and in an economic sense. For example, based on the Carhart (1997) four-factor 
alpha, the underperformance of duality funds in the bottom group is again 3.3 percent. We also find a slight underperformance in the second worst quintile (significant in two out of four cases), but typically no difference in the other quintiles.

Overall, our results suggest that duality managers are not replaced even if they deliver a poor performance. Additional support for this view is also given by the fact that we do not observe a single replacement of duality managers in our sample whereas 122 non-duality managers leave their positions (within 554 distinct non-duality funds in our sample).

\section{Investment Behavior}

If duality managers anticipate their lower replacement risk, we would expect them to incorporate this into their behavior and adjust their investment strategies accordingly. Hence, in this section we test our hypothesis (ii) and examine whether duality managers follow more risky investment strategies than non-duality managers.

Therefore, we analyze the risk-taking behavior of duality managers and investigate the consequences of this behavior on fund performance. We examine whether duality fund managers take more unsystematic risk (Section 4.1) and follow more extreme investment styles (Section 4.2). Finally, we investigate whether differences in risk-taking and investment style lead to more extreme performance outcomes of duality funds (Section 4.3).

\subsection{Unsystematic Risk}

In this section we compare the unsystematic risk level of duality managers to their non-duality peers. We measure the unsystematic risk as the annualized residual standard deviation of Jensen (1968)'s one-factor model, Fama and French (1993)'s three-factor model, 
and Carhart (1997)'s four-factor model, respectively. We then use the unsystematic risk as the dependent variable in the regressions. Results are reported in Table 6.

- Please insert TABLE 6 approximately here -

Our results are in line with hypothesis (ii): duality managers choose significantly (at $1 \%$ level) higher levels of unsystematic risk. The difference is about 1.5 percentage points. Economically, this is a highly significant number since the total unsystematic risk of nonduality funds is only five percent (calculated in unreported analysis).

Regarding the control variables, a fund's turnover ratio and a manager’s MBA degree are positively related to a fund's unsystematic risk. Furthermore, larger funds show lower levels of unsystematic risk, consistent with Chevalier and Ellison (1999).

\subsection{Style Extremity}

Next, we analyze whether duality managers choose more extreme investment styles. To measure the extremity of a fund manager's investment style, we first estimate a Carhart (1997) four-factor model for each fund $i$ in each year $t$. From this model, we use the sensitivities (beta exposures) regarding the size factor ( $S M B)$, the value factor $(H M L)$, and the momentum factor $(M O M)$, respectively, to measure the fund's investment style. We follow Bär, Kempf, and Ruenzi (2011) and construct extremity measures for each style (size, value, and momentum) as:

$$
E M_{i, t}^{S}=\frac{\left|\beta_{i, t}^{S}-\bar{\beta}_{k, t}^{S}\right|}{\frac{1}{N^{k}} \cdot \sum_{j=1}^{N^{k}}\left|\beta_{j, t}^{S}-\bar{\beta}_{k, t}^{S}\right|}
$$

where $S$ represents the investment style analyzed (SMB, HML, and MOM, respectively) and $N^{k}$ gives the number of funds in a specific market segment $k$ in a given 
year t. $E M_{i, t}^{S}$ shows high values for funds which strongly deviate in their exposure to a specific style $\left(\beta_{i, t}^{S}\right)$ from the average exposure of their market segment $\left(\bar{\beta}_{k, t}^{S}\right)$ in absolute terms. We divide the absolute deviation by the average style deviation in the corresponding market segment and respective year to make our style extremity measure comparable across styles, segments, and time. It equals one for the average fund. In addition, we compute an overall extremity measure, $E M_{i, t}$, for each fund by averaging the three style specific extremity measures. We then use the three style extremity measures as well as the overall style extremity measure as dependent variables in our regressions. Results are presented in Table 7.

- Please insert TABLE 7 approximately here -

The results confirm that duality managers follow much more extreme investment styles than non-duality managers. The duality dummy is positive and highly significant in all specifications. The difference is also economically significant: The average extremity measure among duality funds is 1.3 whereas the respective number for the non-duality funds is about 0.95. Putting it differently, only 21 percent of the non-duality managers invest as extremely as the average duality manager (calculated in an unreported analysis).

Regarding the control variables, we find that larger funds follow less extreme investment styles. Furthermore, a higher turnover ratio is typically related to more extreme investment styles. ${ }^{8}$

\footnotetext{
${ }^{8}$ A negative influence of fund size on style extremity and a positive influence of fund's turnover ratio are both consistent with prior literature. See Bär, Kempf, and Ruenzi (2011).
} 


\subsection{Performance Extremity}

In the two sections above, we have shown that duality managers follow more risky and more extreme investment strategies. We now analyze whether this leads to more extreme performance outcomes of duality managers. We follow Bär, Kempf, and Ruenzi (2011) and calculate the extremity measure $E M^{P}$ in each year:

$$
E M_{i, t}^{P}=\frac{\left|P_{i, t}-\bar{P}_{k, t}\right|}{\frac{1}{N^{k}} \cdot \sum_{j=1}^{N^{k}}\left|P_{j, t}-\bar{P}_{k, t}\right|}
$$

where $P$ stands for the respective performance measure and $\bar{P}$ for the average performance of all funds in the same market segment. We measure the performance extremity $E M^{P}$ as the absolute deviation of a fund's performance from the average performance of all funds in the same market segment and divide it by the average absolute deviation of all funds in the segment.

In Table 8 we analyze whether the performance extremity measures differ for duality and non-duality funds. We run regressions where the performance extremity measures are the dependent variables. Performance is measured based on gross returns, but the results remain qualitatively unchanged if we calculate them based on net returns. The most important independent variable in the regressions is again the duality dummy.

\section{- Please insert TABLE 8 approximately here -}

Table 8 clearly shows that duality managers deliver much more extreme performance outcomes than non-duality managers. This finding is consistent with their higher level of unsystematic risk and their more extreme investment style. Based on the Carhart (1997) alpha, the average performance extremity of duality funds is 1.42 whereas it is 0.93 for nonduality funds. This means that only 22 percent of the non-duality managers deliver a performance as extreme as the performance of the average duality fund (calculated in 
unreported analysis). Hence, the duality structure also has serious consequences for the distribution of performance outcomes that go beyond the lower average performance level.

The control variables show that a fund's turnover ratio is positively related to its performance extremity. Furthermore, larger funds show less performance extremity. ${ }^{9}$

\section{Impact of Independent Directors}

Fund manager duality is related to worse average performance and more extreme performance outcomes which are both not desirable from a risk-averse investor's point of view. Thus, it is of severe interest to know what cures the duality conflict. Several studies suggest that a fund's governance is significantly improved if more independent directors are on the board or if independent directors have a higher ownership in the fund and thus a higher motivation to effectively monitor the fund (see, e.g., Fu and Wedge (2011), Cremers, Driessen, Maenhout, and Weinbaum (2009), Ding and Wermers (2009), Ferris and Yan (2007), Khorana, Tufano, and Wedge (2007), U.S. Securities and Exchange Commission (2005), and Tufano and Sevick (1997)). In this section, we test whether more independent board members or a higher fund ownership of these directors reduce the duality conflicts documented above (hypothesis (iii)).

We regress the dependent variables used in the previous sections (performance level, unsystematic risk, style extremity, and performance extremity) on the duality dummy and additionally include interaction terms between the duality dummy and the governance factors as independent variables. The coefficients of these interactions can be interpreted as the impact of the respective governance factor on the duality conflict. For the dependent variables

\footnotetext{
${ }^{9}$ Both results are consistent with the findings of Bär, Kempf, and Ruenzi (2011).
} 
that are based on performance, we again use the fund's gross performance. ${ }^{10}$ We measure independent directors' ownership as the average director's ownership in a specific fund. As ownership information is only disclosed using specified dollar ranges, we use these ranges' respective mean to proxy for a director's ownership in a fund and divide it by 1,000 USD to make the coefficients' magnitude more feasible. ${ }^{11}$ Results are presented in Table 9. Panel A contains results on average performance, Panel B results on unsystematic risk, Panel C results on style extremity, and Panel D results on performance extremity. ${ }^{12}$ The separate impact of each governance factor is presented in Columns (1) and (2), respectively. In Column (3), we include both factors in one regression model.

- Please insert TABLE 9 approximately here -

The results in the first column of Table 9 show that a higher number of independent directors reduces the duality conflict. All coefficients have the expected sign and they are statistically significant in three out of four cases. The significant coefficients suggest that the impact of manager duality disappears if there are about seven independent directors on the board.

Directors' ownership also reduces the duality conflict (see column 2 of Table 9). The respective coefficient is (at least at the 5\%-level) significant in all cases. The estimated coefficients show that the impact of manager duality on performance level disappears if the average independent director invests about 65,000 USD in the fund. To reduce the impact on risk and extreme investment behavior, it requires an even higher independent director’s ownership of up to 100,000 USD which indicates that it is harder to control the duality manager's risky investment behavior. Both numbers are considerably higher than the actual

\footnotetext{
${ }^{10}$ Results (not reported) based on net performance remain qualitatively the same.

${ }^{11}$ For the highest range, which has no upper limit, we assume that a director's ownership equals the range's lower limit (as in Khorana, Servaes, and Wedge (2007)).

${ }^{12}$ For the sake of brevity, we only report results based on Carhart alpha (Panel A), Carhart unsystematic risk (Panel B), average style extremity (Panel C), and Carhart alpha extremity (Panel D). Results using the other measures remain qualitatively the same.
} 
independent director's ownership in duality funds, which equals about 38,000 USD in our sample.

In the last column of Table 9 we include number of independent directors and directors' ownership at the same time. The coefficients of all interaction terms have the opposite sign than the duality effect and, thus, support our hypotheses. However, the independent directors' ownership seems to have a stronger impact on the duality conflict than the number of independent directors. It remains significant in all cases whereas the number of independent directors is significant at conventional levels only in one case.

\section{Conclusion}

Separation of decision making and decision control is the common approach to avoid agency problems when the decision makers do not bear the wealth effects of their decisions. The main task of a mutual fund's board of directors is to oversee the fund's management and, if necessary, replace the fund manager. Thus, a natural conflict of interests arises when the fund manager herself is also serving as the chairman of the board of directors. In our sample, this happens in 14 percent of all funds.

In this paper, we examine the consequences of fund manager duality. We show that duality has severe negative consequences for the fund and its investors. In particular, we document several new findings: (i) Duality managers underperform non-duality managers by about two percent p.a. This underperformance results from worse investment decisions of the duality managers as well as from higher expenses in duality funds. Stratifying the funds into performance quintiles shows that only the bottom quintile makes a difference. The number of duality managers in this quintile is disproportionately high and, in addition, these duality managers deliver a far worse performance than the non-duality managers in this bottom 
quintile. This is consistent with the view that a poorly performing fund manager can avoid being laid off when she chairs the fund board. (ii) Duality managers follow investment strategies different from those of the non-duality managers. They take about one quarter more unsystematic risk and follow much more extreme investment styles. Only about one fifth of the non-duality managers invest as extremely as the average duality manager. Consequently, duality managers deliver far more extreme performance outcomes. These risky strategies are highly sensible for duality managers since they allow them to exploit the convex performance-flow relationship without bearing the risk of being laid off when their bets go wrong. (iii) The effects of manager duality on performance and trading strategy can be reduced by hiring independent members for the fund board. If there are seven independent members in the board, the duality effect is vanished. Independent directors' ownership in the fund works in the same way. It also reduces problems resulting from manager duality. If the independent directors invest about 65,000 USD on average, the effect of manager duality on performance level disappears whereas about 100,000 USD are required to cure the duality impact on investment strategy.

Overall, our paper has important implications for the regulation of mutual funds. In the current discussion about the mandatory number of independent board members and the independence of the board's chair, our results clearly support the SEC's proposal. Fund manager duality hurts the interests of fund investors. 


\section{REFERENCES}

Adams, Renée B., Heitor Almeida, and Daniel Ferreira, 2005, Powerful CEOs and Their Impact on Corporate Performance, Review of Financial Studies 18, 1403-1432.

Bär, Michaela, Alexander Kempf, and Stefan Ruenzi, 2011, Is a Team Different from the Sum of its Parts? Evidence from Mutual Fund Managers, Review of Finance 15, 359396.

Berk, Jonathan B., and Richard C. Green, 2004, Mutual Fund Flows and Performance in Rational Markets, Journal of Political Economy 112, 1269-1295.

Brickley, James A., Jeffrey L. Coles, and Gregg Jarrell, 1997, Leadership Structure: Separating the CEO and Chairman of the Board, Journal of Corporate Finance 3, 189-220.

Cannella, Albert A. Jr., and Michael Lubatkin, 1993, Succession as a Sociopolitical Process: Internal Impediments to Outsider Selection, The Academy of Management Journal 36, 763-793.

Carhart, Mark M., 1997, On Persistence in Mutual Fund Performance, Journal of Finance 52, 57-82.

Chen, Joseph, Harrison Hong, Huang Ming, and Jeffrey D. Kubik, 2004, Does Fund Size Erode Mutual Fund Performance? The Role of Liquidity and Organization, American Economic Review 94, 1276-1302.

Chevalier, Judith, and Glenn Ellison, 1997, Risk Taking by Mutual Funds as a Response to Incentives, Journal of Political Economy 105, 1167-1200.

Chevalier, Judith, and Glenn Ellison, 1999, Career Concerns of Mutual Fund Managers, Quarterly Journal of Economics 114, 389-432.

Cremers, Martijn, Joost Driessen, Pascal Maenhout, and David Weinbaum, 2009, Does Skin in the Game Matter? Director Incentives and Governance in the Mutual Fund Industry, Journal of Financial And Quantitative Analysis 44, 1345-1373.

Del Guercio, Diane, Larry Y. Dann, and M. Megan Partch, 2003, Governance and Boards of Directors in Closed-End Investment Companies, Journal of Financial Economics 69, 111-152.

Ding, Bill, and Russell Wermers, 2009, Mutual Fund Performance and Governance Structure: The Role of Portfolio Managers and Boards of Directors, Working Paper.

Fama, Eugene F., and Kenneth R. French, 1993, Common Risk Factors in the Returns on Stocks and Bonds, Journal of Financial Economics 33, 3-56.

Fama, Eugene F., and Michael C. Jensen, 1983, Separation of Ownership and Control, Journal of Law and Economics 26, 301-325.

Ferris, Stephen P., and Xuemin Yan, 2007, Do independent directors and chairmen matter? The role of boards of directors in mutual fund governance, Journal of Corporate Finance 13, 392-420.

Fu, Richard, and Lei Wedge, 2011, Board Independence and Mutual Fund Manager Turnover, Financial Review 46, 621-641.

Golec, Joseph H., 1996, The Effects of Mutual Fund Managers' Characteristics on Their Portfolio Performance, Risk and Fees, Financial Services Review 5, 133-148.

Gottesman, Aron A., and Matthew R. Morey, 2006, Manager Education and Mutual Fund Performance, Journal of Empirical Finance 13, 145-182.

Goyal, Vidhan K., and Chul W. Park, 2002, Board Leadership Structure and CEO Turnover, Journal of Corporate Finance 8, 49-66.

Jensen, Michael C., 1968, The Performance of Mutual Funds in the Period 1945-1964, Journal of Finance 23, 389-416. 
Khorana, Ajay, Henri Servaes, and Lei Wedge, 2007, Portfolio Manager Ownership and Fund Performance, Journal of Financial Economics 85, 179-204.

Khorana, Ajay, Peter Tufano, and Lei Wedge, 2007, Board Structure, Mergers, and Shareholder Wealth: A Study of the Mutual Fund Industry, Journal of Financial Economics 85, 571-598.

Rechner, Paula K., and Dan R. Dalton, 1991, CEO Duality and Organizational Performance: A Longitudinal Analysis, Strategic Management Journal 12, 155-160.

Tufano, Peter, and Matthew Sevick, 1997, Board Structure and Fee-Setting in the U.S. Mutual Fund Industry, Journal of Financial Economics 46, 321-355.

U.S. Securities and Exchange Commission, 2005, Exemptive Rule Amendments of 2004: The Independent Chair Condition, Washington, D.C.: U.S. Securities and Exchange Commission, www.sec.gov/news/studies/indchair.pdf. 


\section{Table 1 - Descriptive Statistics}

This table reports summary statistics for our sample of single-managed US equity mutual funds between 2005 and 2009. The actively managed, domestic equity funds are grouped into seven segments: Aggressive Growth, Growth and Income, Income, Growth, Sector Funds, Utility Funds, and Mid-Cap Funds. For each sample year as well as the average over the total sample, we report the number of funds in the sample, funds' total net assets (TNA), fund's expense ratio, funds' age, and the turnover of the fund. Our sample only contains funds for which at least 12 months of return data is available.

\begin{tabular}{cccccc}
\hline Year & $\begin{array}{c}\text { Number of } \\
\text { Funds }\end{array}$ & $\begin{array}{c}\text { Mean TNA } \\
\text { in Million USD }\end{array}$ & $\begin{array}{c}\text { Mean Expense } \\
\text { Ratio }\end{array}$ & $\begin{array}{c}\text { Mean } \\
\text { Fund Age }\end{array}$ & $\begin{array}{c}\text { Mean } \\
\text { Turnover }\end{array}$ \\
\hline 2005 & 393 & $1,780.9$ & $1.45 \%$ & 16 & $85.08 \%$ \\
2006 & 425 & $1,807.1$ & $1.36 \%$ & 16 & $94.53 \%$ \\
2007 & 432 & $1,992.1$ & $1.29 \%$ & 16 & $85.52 \%$ \\
2008 & 347 & $1,163.1$ & $1.22 \%$ & 18 & $99.93 \%$ \\
2009 & 310 & $1,532.9$ & $1.24 \%$ & 18 & $101.23 \%$ \\
\hline Total sample & 636 & $1,681.9$ & $1.32 \%$ & 17 & $92.61 \%$ \\
\hline
\end{tabular}




\section{Table 2 - Fund and Manager Characteristics and Duality}

This table reports summary statistics for various fund and manager characteristics of funds for which the manager also serves as the chairman of the board of directors (Duality) and those funds whose managers do not (Non-duality). The fund characteristics analyzed are the fraction of funds managed, the funds' size as measured by the TNA in million USD, the expense ratio, the management fee, the funds' age, and the funds' turnover. The manager characteristics include the mangers' industry tenure, the fraction of male managers, the fraction of managers with an MBA, the fraction of managers with a CFA, and the fraction of managers with a PhD. The managers' industry tenure is calculated from the year that Morningstar reports for a manager to be the first year managing any fund in the Morningstar database. The manager's gender is determined following Niessen-Ruenzi and Ruenzi (2011) by comparing the manager's first name to a list published by the United States Social Security Administration (SSA) that contains the most popular first names by gender for the last 10 decades. Additionally, we identify the gender of managers with ambiguous first names from several internet sources like the fund prospectus, press releases, or photographs that reveal their gender. The last column of the table reports the difference in fund and manager characteristics between duality and non-duality funds. ***, **, and * denote statistical significance for the difference in means between both groups based on t-test at the 1\%-, 5\%-, and $10 \%$-level, respectively.

\begin{tabular}{lrrc}
\hline & Duality & Non-duality & Difference \\
\hline Funds Managed (fraction in \%) & 13.69 & 86.31 & - \\
& & & \\
Fund characteristics: & & & \\
Fund Size (in million USD) & 901.93 & $1,813.49$ & $-911.56^{* * *}$ \\
Expense Ratio (\%) & 1.70 & 1.26 & $0.44^{* * *}$ \\
Management Fee (\%) & 0.66 & 0.56 & 0.10 \\
Fund Age & 16.00 & 17.00 & -1.00 \\
Turnover (\%) & 92.06 & 92.69 & 0.63 \\
& & & \\
Manager characteristics: & & & \\
Industry Tenure & 17.00 & 10.00 & $7.00^{* * *}$ \\
Male (fraction in \%) & 99.61 & 91.17 & $8.44^{* * *}$ \\
MBA (fraction in \%) & 54.41 & 38.88 & $15.52^{* * *}$ \\
CFA (fraction in \%) & 32.95 & 29.28 & 3.67 \\
PhD (fraction in \%) & 2.29 & 1.15 & 1.14 \\
\hline
\end{tabular}




\section{Table 3 - Overall Performance Level}

This table reports results from pooled OLS regressions of yearly net-of-fess (Panel A) and gross-of-fees (Panel B) performance measures as dependent variables on the duality dummy as main independent variable. We use four different performance measures: (1) objective-adjusted returns (OAR), (2) Jensen (1968)'s one-factor alpha, (3) Fama and French (1993) three-factor alpha (FF), and (4) Carhart (1997) four-factor alpha. The duality dummy equals one if the fund's manager also serves as the chairman of the fund's board of directors and zero otherwise. Ln(Size) is defined as the natural logarithm of a fund's lagged TNA. Other independent variables are defined as in Table 2. All regression specifications include time fixed effects. Models (2), (3), and (4) also include segment fixed effects. Robust p-values of the regression coefficients in parentheses are based on standard errors clustered by fund. ***, **, and * denote statistical significance at the 1\%-, 5\%-, and 10\%-level, respectively.

Panel A: Net Performance

\begin{tabular}{|c|c|c|c|c|}
\hline $\begin{array}{l}\text { Dependent variable: } \\
\text { Model: }\end{array}$ & $\begin{array}{l}\text { OAR } \\
(1)\end{array}$ & $\begin{array}{c}\text { Jensen Alpha } \\
\text { (2) }\end{array}$ & $\begin{array}{c}\text { FF Alpha } \\
\text { (3) } \\
\end{array}$ & $\begin{array}{l}\text { Carhart Alpha } \\
\text { (4) }\end{array}$ \\
\hline Duality & $\begin{array}{l}-0.0153 * * \\
(0.023)\end{array}$ & $\begin{array}{l}-0.0184^{* *} \\
(0.020)\end{array}$ & $\begin{array}{l}-0.0217 * * * \\
(0.006)\end{array}$ & $\begin{array}{l}-0.0247 * * * \\
(0.001)\end{array}$ \\
\hline \multicolumn{5}{|l|}{ Fund characteristics: } \\
\hline $\operatorname{Ln}($ Size $)$ & $\begin{array}{r}-0.0003 \\
(0.793)\end{array}$ & $\begin{array}{l}0.0018 \\
(0.168)\end{array}$ & $\begin{array}{l}0.0005 \\
(0.680)\end{array}$ & $\begin{array}{l}-0.0009 \\
(0.439)\end{array}$ \\
\hline Turnover & $\begin{array}{r}-0.0028 \\
(0.312)\end{array}$ & $\begin{array}{l}-0.0133^{* * *} \\
(<0.001)\end{array}$ & $\begin{array}{l}-0.0141^{* * *} \\
(<0.001)\end{array}$ & $\begin{array}{l}-0.0184^{* * *} \\
(<0.001)\end{array}$ \\
\hline Fund Age & $\begin{array}{l}0.0002 * \\
(0.057)\end{array}$ & $\begin{array}{r}0.0002 \\
(0.118)\end{array}$ & $\begin{array}{r}0.0001 \\
(0.555)\end{array}$ & $\begin{array}{r}0.0000 \\
(0.914)\end{array}$ \\
\hline \multicolumn{5}{|c|}{ Manager characteristics: } \\
\hline MBA & $\begin{array}{l}0.0092 * * \\
(0.023)\end{array}$ & $\begin{array}{l}0.0082^{*} \\
(0.084)\end{array}$ & $\begin{array}{l}0.0000 \\
(0.993)\end{array}$ & $\begin{array}{r}-0.0022 \\
(0.645)\end{array}$ \\
\hline CFA & $\begin{array}{l}0.0014 \\
(0.738)\end{array}$ & $\begin{array}{l}0.0047 \\
(0.328)\end{array}$ & $\begin{array}{l}0.0083^{*} \\
(0.072)\end{array}$ & $\begin{array}{r}0.0046 \\
(0.325)\end{array}$ \\
\hline $\mathrm{PhD}$ & $\begin{array}{l}0.0291 * \\
(0.053)\end{array}$ & $\begin{array}{r}0.0208 \\
(0.317)\end{array}$ & $\begin{array}{l}0.0065 \\
(0.712)\end{array}$ & $\begin{array}{r}0.0255 \\
(0.184)\end{array}$ \\
\hline Industry Tenure & $\begin{array}{r}0.0001 \\
(0.896)\end{array}$ & $\begin{array}{r}-0.0004 \\
(0.369)\end{array}$ & $\begin{array}{r}-0.0007 \\
(0.143)\end{array}$ & $\begin{array}{r}-0.0002 \\
(0.607)\end{array}$ \\
\hline Segment fixed effects & No & Yes & Yes & Yes \\
\hline Time fixed effects & Yes & Yes & Yes & Yes \\
\hline Observations & 1,894 & 1,894 & 1,894 & 1,894 \\
\hline $\mathrm{R}^{2}$ & $1.61 \%$ & $13.76 \%$ & $10.41 \%$ & $7.16 \%$ \\
\hline
\end{tabular}


Table 3 - Continued

Panel B: Gross Performance

\begin{tabular}{|c|c|c|c|c|}
\hline $\begin{array}{l}\text { Dependent variable: } \\
\text { Model: }\end{array}$ & $\begin{array}{l}\text { OAR } \\
\text { (1) }\end{array}$ & $\begin{array}{c}\text { Jensen Alpha } \\
\text { (2) }\end{array}$ & $\begin{array}{l}\text { FF Alpha } \\
\text { (3) }\end{array}$ & $\begin{array}{l}\text { Carhart Alpha } \\
\text { (4) }\end{array}$ \\
\hline Duality & $\begin{array}{l}-0.0128 * * \\
(0.040)\end{array}$ & $\begin{array}{l}-0.0155^{* *} \\
(0.030)\end{array}$ & $\begin{array}{l}-0.0188 * * \\
(0.013)\end{array}$ & $\begin{array}{l}-0.0218^{* * *} \\
(0.004)\end{array}$ \\
\hline \multicolumn{5}{|l|}{ Fund characteristics: } \\
\hline Ln(Size) & $\begin{array}{l}-0.0016 * \\
(0.096)\end{array}$ & $\begin{array}{l}0.0004 \\
(0.723)\end{array}$ & $\begin{array}{r}-0.0010 \\
(0.374)\end{array}$ & $\begin{array}{l}-0.0024^{* *} \\
(0.031)\end{array}$ \\
\hline Turnover & $\begin{array}{r}-0.0024 \\
(0.347)\end{array}$ & $\begin{array}{l}-0.0128^{* * *} \\
(<0.001)\end{array}$ & $\begin{array}{l}-0.0135^{* * *} \\
(<0.001)\end{array}$ & $\begin{array}{l}-0.0178^{* * *} \\
(<0.001)\end{array}$ \\
\hline Fund Age & $\begin{array}{l}0.0003^{* *} \\
(0.011)\end{array}$ & $\begin{array}{l}0.0003 * * \\
(0.036)\end{array}$ & $\begin{array}{r}0.0001 \\
(0.276)\end{array}$ & $\begin{array}{r}0.0000 \\
(0.738)\end{array}$ \\
\hline \multicolumn{5}{|c|}{ Manager characteristics: } \\
\hline MBA & $\begin{array}{l}0.0084^{* *} \\
(0.037)\end{array}$ & $\begin{array}{r}0.0072 \\
(0.123)\end{array}$ & $\begin{array}{r}-0.0010 \\
(0.839)\end{array}$ & $\begin{array}{r}-0.0032 \\
(0.508)\end{array}$ \\
\hline CFA & $\begin{array}{r}0.0016 \\
(0.685)\end{array}$ & $\begin{array}{r}0.0049 \\
(0.288)\end{array}$ & $\begin{array}{l}0.0086^{*} \\
(0.057)\end{array}$ & $\begin{array}{r}0.0048 \\
(0.286)\end{array}$ \\
\hline $\mathrm{PhD}$ & $\begin{array}{l}0.0275^{*} \\
(0.062)\end{array}$ & $\begin{array}{r}0.0187 \\
(0.365)\end{array}$ & $\begin{array}{r}0.0044 \\
(0.802)\end{array}$ & $\begin{array}{r}0.0234 \\
(0.223)\end{array}$ \\
\hline Industry Tenure & $\begin{array}{r}0.0001 \\
(0.846)\end{array}$ & $\begin{array}{r}-0.0004 \\
(0.386)\end{array}$ & $\begin{array}{r}-0.0006 \\
(0.156)\end{array}$ & $\begin{array}{r}-0.0002 \\
(0.655)\end{array}$ \\
\hline Segment fixed effects & No & Yes & Yes & Yes \\
\hline Time fixed effects & Yes & Yes & Yes & Yes \\
\hline Observations & 1,894 & 1,894 & 1,894 & 1,894 \\
\hline $\mathrm{R}^{2}$ & $1.35 \%$ & $13.38 \%$ & $10.07 \%$ & $6.82 \%$ \\
\hline
\end{tabular}




\section{Table 4 - Quintiles Performance Level}

This table reports results on gross-of-fees performance difference between duality funds and non-duality funds in different performance quintiles. In each year of our sample, we sort all funds into five equal sized groups according to their performance of the respective year. Panels A-D present the average performance within each quintile for duality and non-duality funds using four different performance measures: (1) objective-adjusted returns (OAR), (2) Jensen (1968)'s one-factor alpha, (3) Fama and French (1993) three-factor alpha (FF), and (4) Carhart (1997) four-factor alpha. The last column of Panels A-D reports the performance difference between duality and non-duality funds in each quintile. ***, **, and * denote statistical significance at the $1 \%-, 5 \%-$, and $10 \%$-level, respectively, for the difference in means between both groups based on t-tests.

Panel A: OAR

\begin{tabular}{cccc}
\hline Quintile & Duality & Non-duality & Difference \\
\hline 1 (Top) & 0.134 & 0.125 & 0.008 \\
2 & 0.043 & 0.041 & 0.002 \\
3 & 0.002 & 0.003 & -0.001 \\
4 & -0.036 & -0.037 & 0.001 \\
5 (Bottom) & -0.123 & -0.105 & $-0.018^{* *}$ \\
\hline
\end{tabular}

Panel B: Jensen Alpha

\begin{tabular}{cccc}
\hline Quintile & Duality & Non-duality & Difference \\
\hline 1 (Top) & 0.116 & 0.139 & $-0.023^{* *}$ \\
2 & 0.055 & 0.051 & 0.003 \\
3 & 0.004 & 0.007 & -0.003 \\
4 & -0.026 & -0.037 & 0.012 \\
5 (Bottom) & -0.145 & -0.110 & $-0.035^{* * *}$ \\
\hline
\end{tabular}

Panel C: FF Alpha

\begin{tabular}{cccc}
\hline Quintile & Duality & Non-duality & Difference \\
\hline 1 (Top) & 0.118 & 0.131 & -0.012 \\
2 & 0.050 & 0.050 & 0.000 \\
3 & 0.012 & 0.011 & 0.002 \\
4 & -0.023 & -0.024 & 0.001 \\
5 (Bottom) & -0.133 & -0.104 & $-0.029 * * *$ \\
\hline
\end{tabular}

Panel D: Carhart Alpha

\begin{tabular}{cccc}
\hline Quintile & Duality & Non-duality & Difference \\
\hline 1 (Top) & 0.122 & 0.133 & -0.011 \\
2 & 0.051 & 0.053 & -0.002 \\
3 & 0.011 & 0.012 & 0.000 \\
4 & -0.017 & -0.020 & 0.003 \\
5 (Bottom) & -0.137 & -0.104 & $-0.033^{* *}$ \\
\hline
\end{tabular}




\section{Table 5 - Quintiles Performance Regressions}

This table reports results from pooled OLS regressions of yearly gross-of-fees performance measures as dependent variables on the duality dummy as main independent variable in each quintile. Panels A-E are based on subsamples of funds within each quintile using four different performance measures: (1) objective-adjusted returns (OAR), (2) Jensen (1968)'s one-factor alpha, (3) Fama and French (1993) three-factor alpha (FF), and (4) Carhart (1997) four-factor alpha. The duality dummy equals one if the fund's manager also serves as the chairman of the fund's board of directors and zero otherwise. Other independent variables are defined in Tables 2 and 3. All regression specifications include time fixed effects. Models (2), (3), and (4) also include segment fixed effects. Robust p-values of the regression coefficients in parentheses are based on standard errors clustered by fund. $* * *, * *$, and * denote statistical significance at the 1\%-, 5\%-, and 10\%-level, respectively.

Panel A: Quintile 1 (Top)

\begin{tabular}{|c|c|c|c|c|}
\hline $\begin{array}{l}\text { Dependent variable: } \\
\text { Model: }\end{array}$ & $\begin{array}{l}\text { OAR } \\
(1)\end{array}$ & $\begin{array}{c}\text { Jensen Alpha } \\
(2) \\
\end{array}$ & $\begin{array}{c}\text { FF Alpha } \\
\text { (3) }\end{array}$ & $\begin{array}{c}\text { Carhart Alpha } \\
(4)\end{array}$ \\
\hline Duality & $\begin{array}{l}0.0179 * \\
(0.054)\end{array}$ & $\begin{array}{r}0.0029 \\
(0.707)\end{array}$ & $\begin{array}{r}0.0063 \\
(0.568)\end{array}$ & $\begin{array}{r}0.0083 \\
(0.285)\end{array}$ \\
\hline Fund and manager characteristics & Yes & Yes & Yes & Yes \\
\hline Segment fixed effects & No & Yes & Yes & Yes \\
\hline Time fixed effects & Yes & Yes & Yes & Yes \\
\hline Observations & 378 & 378 & 378 & 378 \\
\hline $\mathrm{R}^{2}$ & $32.65 \%$ & $41.34 \%$ & $25.55 \%$ & $13.56 \%$ \\
\hline
\end{tabular}

Panel B: Quintile 2

\begin{tabular}{lcccr} 
Dependent variable: & OAR & Jensen Alpha & FF Alpha & \multicolumn{2}{c}{ Carhart Alpha } \\
Model: & $(1)$ & $(2)$ & $(3)$ & 0.0034 \\
\hline Duality & 0.0037 & -0.0001 & $(0.234)$ & $(0.951)$ \\
& $(0.118)$ & $(0.983)$ & Yes & Yes \\
Fund and manager characteristics & Yes & Yes & Yes & Yes \\
Segment fixed effects & No & Yes & Yes & Yes \\
Time fixed effects & Yes & 379 & 378 & 379 \\
Observations & 378 & $81.05 \%$ & $54.86 \%$ & $20.77 \%$ \\
$\mathrm{R}^{2}$ & $58.79 \%$ & &
\end{tabular}

Panel C: Quintile 3

\begin{tabular}{lcccc}
\hline Dependent variable: & OAR & Jensen Alpha & FF Alpha & \multicolumn{2}{c}{ Carhart Alpha } \\
Model: & $(1)$ & $(2)$ & $(3)$ & -0.0005 \\
\hline Duality & -0.0015 & -0.0023 & -0.0010 & $(0.799)$ \\
& $(0.362)$ & $(0.391)$ & $(0.627)$ & Yes \\
Fund and manager characteristics & Yes & Yes & Yes & Yes \\
Segment fixed effects & No & Yes & Yes & Yes \\
Time fixed effects & Yes & Yes & 380 & 380 \\
Observations & 380 & $82.62 \%$ & $74.90 \%$ & $40.35 \%$ \\
$\mathrm{R}^{2}$ & $36.50 \%$ & &
\end{tabular}


Table 5 - Continued

Panel D: Quintile 4

\begin{tabular}{|c|c|c|c|c|}
\hline $\begin{array}{l}\text { Dependent variable: } \\
\text { Model: }\end{array}$ & $\begin{array}{c}\text { OAR } \\
(1) \\
\end{array}$ & $\begin{array}{c}\text { Jensen Alpha } \\
(2) \\
\end{array}$ & $\begin{array}{l}\text { FF Alpha } \\
\text { (3) } \\
\end{array}$ & $\begin{array}{c}\text { Carhart Alpha } \\
(4)\end{array}$ \\
\hline Duality & $\begin{array}{l}-0.0004 \\
(0.855)\end{array}$ & $\begin{array}{r}0.0028 \\
(0.271)\end{array}$ & $\begin{array}{l}-0.0038 * \\
(0.070)\end{array}$ & $\begin{array}{c}-0.0035 * \\
(0.095)\end{array}$ \\
\hline Fund and manager characteristics & Yes & Yes & Yes & Yes \\
\hline Segment fixed effects & No & Yes & Yes & Yes \\
\hline Time fixed effects & Yes & Yes & Yes & Yes \\
\hline Observations & 378 & 378 & 378 & 377 \\
\hline $\mathrm{R}^{2}$ & $24.79 \%$ & $85.70 \%$ & $67.04 \%$ & $52.27 \%$ \\
\hline
\end{tabular}

Panel E: Quintile 5 (Bottom)

\begin{tabular}{lcccc} 
Dependent variable: & OAR & Jensen Alpha & FF Alpha & Carhart Alpha \\
Model: & $(1)$ & $(2)$ & $(3)$ & $(4)$ \\
\hline Duality & $-0.0168^{*}$ & $-0.0289 * * *$ & $-0.0296 * * *$ & $-0.0333^{* * *}$ \\
& $(0.056)$ & $(0.001)$ & $(0.004)$ & $(0.008)$ \\
Fund and manager characteristics & Yes & Yes & Yes & Yes \\
Segment fixed effects & No & Yes & Yes & Yes \\
Time fixed effects & Yes & Yes & Yes & Yes \\
\hline Observations & 380 & 379 & 380 & 380 \\
$\mathrm{R}^{2}$ & $23.24 \%$ & $44.91 \%$ & $35.74 \%$ & $28.18 \%$ \\
\hline
\end{tabular}




\section{Table 6 - Unsystematic Risk}

This table presents results from pooled OLS regressions of yearly unsystematic risk level measures as dependent variable on the duality dummy as main independent variable. The duality dummy equals one if the fund's manager also serves as the chairman of the fund's board of directors and zero otherwise. To measure the fund's unsystematic risk, we first estimate for each fund in each year the (1) Jensen (1968) one-factor model, the (2) Fama and French (1993) three-factor model (FF), and the (3) Carhart (1997) four-factor model. We then compute the unsystematic risk as the standard deviation of the residuals from the regressions. Other independent variables are defined in Tables 2 and 3. All regression specifications include time fixed effects and segment fixed effects. Robust p-values of the regression coefficients in parentheses are based on standard errors clustered by fund. $* * *, * *$, and * denote statistical significance at the 1\%-, 5\%-, and 10\%-level, respectively.

\begin{tabular}{lccc}
\hline \multirow{2}{*}{ Dependent variable: } & \multicolumn{3}{c}{ Unsystematic Risk } \\
\cline { 2 - 4 } Model: & Jensen & FF & Carhart \\
\hline Duality & $(1)$ & $(2)$ & $(3)$ \\
Fund characteristics: & $\left(<0.0148^{* * *}\right.$ & $0.0142^{* * *}$ & $0.0133^{* * *}$ \\
Ln(Size) & & $(<0.001)$ & $(<0.001)$ \\
& $-0.0019 * * *$ & $-0.0011^{* *}$ & $-0.0010^{* *}$ \\
Turnover & $(0.001)$ & $(0.015)$ & $(0.019)$ \\
& $0.0082^{* * *}$ & $0.0068 * * *$ & $0.0055^{* * *}$ \\
Fund Age & $(<0.001)$ & $(<0.001)$ & $(<0.001)$ \\
& $0.0001^{*}$ & 0.0001 & 0.0001 \\
Manager characteristics: & $(0.077)$ & $(0.271)$ & $(0.238)$ \\
MBA & & & \\
& $0.0037^{*}$ & 0.0009 & 0.0013 \\
CFA & $(0.076)$ & $(0.575)$ & $(0.371)$ \\
& 0.0014 & 0.0001 & 0.0006 \\
PhD & $(0.500)$ & $(0.942)$ & $(0.669)$ \\
& 0.0016 & -0.0019 & -0.0035 \\
Industry Tenure & $(0.849)$ & $(0.786)$ & $(0.389)$ \\
Segment fixed effects & Yes & -0.0001 & -0.0001 \\
Time fixed effects & -0.0001 & $(0.444)$ & $(0.250)$ \\
Observations & $(0.556)$ & Yes & Yes \\
\hline
\end{tabular}




\section{Table 7 - Style Extremity}

This table reports results from pooled OLS regression of yearly gross-of-fees style extremity measures as dependent variables on the duality dummy as main independent variable. The duality dummy equals one if the fund's manager also serves as the chairman of the fund's board of directors and zero otherwise. To quantify style extremity we first estimate the following Carhart (1997) four-factor model for each fund $i$ in each year $t$ :

$$
r_{i, m, t}-r_{f, m, t}=\alpha_{i, t}+\beta_{i, t}^{M k t} \cdot\left(r_{M k t, m, t}-r_{f, m, t}\right)+\beta_{i, t}^{S M B} \cdot S M B_{m, t}+\beta_{i, t}^{H M L} \cdot H M L_{m, t}+\beta_{i, t}^{M O M} \cdot M O M_{m, t}+\varepsilon_{i, m, t}
$$

where $r_{i, m, t}$ is the monthly return of fund $i$ in month $m$ of year $t, r_{f, m, t}$ is the risk-free rate, and $r_{M k t, m, t}$ is the market return and $S M B, H M L$, and $M O M$ are the returns of factor-mimicking portfolios. We then follow the approach of Bär, Kempf, and Ruenzi (2011) and calculate an extremity measure $E M^{S}$ in each year:

$$
E M_{i, t}^{S}=\frac{\left|\beta_{i, t}^{S}-\bar{\beta}_{k, t}^{S}\right|}{\frac{1}{N^{k}} \cdot \sum_{j=1}^{N^{k}}\left|\beta_{j, t}^{S}-\bar{\beta}_{k, t}^{S}\right|}
$$

where $S$ represents the investment style analyzed (SMB, HML, and $M O M$, respectively) and $N^{k}$ gives the number of funds in a specific market segment $k$ in a given year $t$. To normalize the extremity measure, we divide it by the average style deviation in the corresponding market segment and respective year. Additionally, we calculate the average style extremity measure, $E M$, for each fund across the three investment styles as:

$$
E M_{i, t}=\frac{1}{3} \cdot\left(E M_{i, t}^{S M B}+E M_{i, t}^{H M L}+E M_{i, t}^{M O M}\right)
$$

Other independent variables are defined in Tables 2 and 3. All regression specifications include time fixed effects and segment fixed effects. Robust p-values of the regression coefficients in parentheses are based on standard errors clustered by fund. ***, **, and * denote statistical significance at the 1\%-, 5\%-, and 10\%-level, respectively.

\begin{tabular}{lcccc}
\hline Dependent variable: & $\begin{array}{c}\text { SMB } \\
\text { Extremity } \\
\text { Model: }\end{array}$ & $\begin{array}{c}\text { HML } \\
\text { Extremity } \\
(1)\end{array}$ & $\begin{array}{c}\text { MOM } \\
\text { Extremity } \\
(3)\end{array}$ & $\begin{array}{c}\text { Average } \\
\text { Extremity } \\
(4)\end{array}$ \\
\hline Duality & $0.2899 * * *$ & $0.3546^{* * *}$ & $0.3533^{* * *}$ & $0.3326^{* * *}$ \\
& $(0.002)$ & $(0.001)$ & $(<0.001)$ & $(<0.001)$ \\
Fund characteristics: & & & $-0.0314 * *$ & $-0.0313^{* *}$ \\
Ln(Size) & $-0.0463 * *$ & -0.0161 & $(0.024)$ & $(0.014)$ \\
& $(0.019)$ & $(0.264)$ & $0.1514 * * *$ & $0.1470 * * *$ \\
Turnover & $0.1222 * * *$ & $0.1674^{* * *}$ & $(<0.001)$ & $(<0.001)$ \\
& $(<0.001)$ & $(0.001)$ & 0.0003 & 0.0011 \\
Fund Age & 0.0022 & 0.0008 & $(0.880)$ & $(0.445)$ \\
& $(0.274)$ & $(0.645)$ & & \\
Manager characteristics: & & & -0.0169 & 0.0406 \\
MBA & $0.1161 * *$ & 0.0226 & $(0.735)$ & $(0.319)$ \\
& $(0.042)$ & $(0.681)$ & -0.0014 & 0.0549 \\
CFA & 0.0704 & 0.0956 & $(0.981)$ & $(0.211)$ \\
& $(0.243)$ & $(0.133)$ & 0.2348 & 0.1066 \\
PhD & -0.0312 & 0.1162 & $(0.621)$ & $(0.455)$ \\
& $(0.880)$ & $(0.646)$ & -0.0020 & -0.0048 \\
Industry Tenure & -0.0074 & -0.0051 & $(0.675)$ & $(0.224)$ \\
& $(0.149)$ & $(0.359)$ & Yes & Yes \\
Segment fixed effects & Yes & Yes & Yes & Yes \\
Time fixed effects & Yes & Yes & 1,894 & 1,894 \\
Observations & 1,894 & 1,894 & $8.99 \%$ & $10.51 \%$ \\
$\mathrm{R}^{2}$ & $8.41 \%$ & $7.18 \%$ & & \\
\hline
\end{tabular}




\section{Table 8 - Performance Extremity}

This table reports results from pooled OLS regression of yearly gross-of-fees performance extremity measures as dependent variables on the duality dummy as main independent variable. The duality dummy equals one if the fund's manager also serves as the chairman of the fund's board of directors and zero otherwise. To quantify performance extremity we follow the approach of Bär, Kempf, and Ruenzi (2011) and calculate an extremity measure $E M^{P}$ in each year:

$$
E M_{i, t}^{P}=\frac{\left|P_{i, t}-\bar{P}_{k, t}\right|}{\frac{1}{N^{k}} \cdot \sum_{j=1}^{N^{k}}\left|P_{j, t}-\bar{P}_{k, t}\right|}
$$

where $P$ stands for the respective performance measure. We measure the performance extremity $E M^{P}$ as the absolute deviation of a fund's performance from the average performance of all funds in the same market segment and divided by the average absolute deviation of all funds in the segment. We use the extremity of all four performance measures as dependent variables. Other independent variables are defined in Tables 2 and 3. All regression specifications include time fixed effects. Models (2), (3), and (4) also include segment fixed effects. Robust p-values of the regression coefficients in parentheses are based on standard errors clustered by fund. $* * *, * *$, and * denote statistical significance at the 1\%-, 5\%-, and 10\%-level, respectively.

\begin{tabular}{|c|c|c|c|c|}
\hline $\begin{array}{l}\text { Dependent variable: } \\
\text { Model: }\end{array}$ & $\begin{array}{c}\text { OAR } \\
\text { Extremity } \\
(1) \\
\end{array}$ & $\begin{array}{l}\text { Jensen Alpha } \\
\text { Extremity } \\
(2) \\
\end{array}$ & $\begin{array}{l}\text { FF Alpha } \\
\text { Extremity } \\
\quad(3)\end{array}$ & $\begin{array}{l}\text { Carhart Alpha } \\
\text { Extremity } \\
(4) \\
\end{array}$ \\
\hline Duality & $\begin{array}{l}0.3666 * * * \\
(<0.001)\end{array}$ & $\begin{array}{l}0.3971 * * * \\
(<0.001)\end{array}$ & $\begin{array}{l}0.4526 * * * \\
(<0.001)\end{array}$ & $\begin{array}{l}0.4698 * * * \\
(<0.001)\end{array}$ \\
\hline \multicolumn{5}{|l|}{ Fund characteristics: } \\
\hline $\operatorname{Ln}($ Size $)$ & $\begin{array}{l}-0.0324 * * \\
(0.012)\end{array}$ & $\begin{array}{l}-0.0342 * * \\
(0.010)\end{array}$ & $\begin{array}{l}-0.0482 * * * \\
(<0.001)\end{array}$ & $\begin{array}{l}-0.0424 * * * \\
(0.001)\end{array}$ \\
\hline Turnover & $\begin{array}{l}0.1824 * * * \\
(<0.001)\end{array}$ & $\begin{array}{l}0.1694 * * * \\
(<0.001)\end{array}$ & $\begin{array}{l}0.1903 * * * \\
(<0.001)\end{array}$ & $\begin{array}{l}0.2455 * * * \\
(0.002)\end{array}$ \\
\hline Fund Age & $\begin{array}{l}-0.0008 \\
(0.632)\end{array}$ & $\begin{array}{l}-0.0002 \\
(0.876)\end{array}$ & $\begin{array}{l}0.0003 \\
(0.864)\end{array}$ & $\begin{array}{l}0.0011 \\
(0.492)\end{array}$ \\
\hline Manager characteristic & & & & \\
\hline MBA & $\begin{array}{l}-0.0273 \\
(0.554)\end{array}$ & $\begin{array}{l}0.0056 \\
(0.903)\end{array}$ & $\begin{array}{l}0.0362 \\
(0.466)\end{array}$ & $\begin{array}{l}0.0646 \\
(0.198)\end{array}$ \\
\hline CFA & $\begin{array}{l}0.1202 * * \\
(0.023)\end{array}$ & $\begin{array}{l}0.0512 \\
(0.327)\end{array}$ & $\begin{array}{l}-0.0320 \\
(0.565)\end{array}$ & $\begin{array}{l}-0.0108 \\
(0.853)\end{array}$ \\
\hline $\mathrm{PhD}$ & $\begin{array}{l}0.1978 \\
(0.405)\end{array}$ & $\begin{array}{l}-0.0441 \\
(0.877)\end{array}$ & $\begin{array}{l}0.1016 \\
(0.696)\end{array}$ & $\begin{array}{l}-0.1995 \\
(0.347)\end{array}$ \\
\hline Industry Tenure & $\begin{array}{l}0.0007 \\
(0.853)\end{array}$ & $\begin{array}{r}-0.0059 \\
(0.140)\end{array}$ & $\begin{array}{l}0.0024 \\
(0.647)\end{array}$ & $\begin{array}{r}-0.0029 \\
(0.554)\end{array}$ \\
\hline $\begin{array}{l}\text { Segment fixed effects } \\
\text { Time fixed effects }\end{array}$ & $\begin{array}{r}\text { No } \\
\text { Yes } \\
\end{array}$ & $\begin{array}{l}\text { Yes } \\
\text { Yes }\end{array}$ & $\begin{array}{l}\text { Yes } \\
\text { Yes }\end{array}$ & $\begin{array}{l}\text { Yes } \\
\text { Yes }\end{array}$ \\
\hline Observations & 1,894 & 1,894 & 1,894 & 1,894 \\
\hline $\mathrm{R}^{2}$ & $8.99 \%$ & $8.11 \%$ & $9.90 \%$ & $11.41 \%$ \\
\hline
\end{tabular}




\section{Table 9 - Impact of Independent Directors}

This table presents results from pooled OLS regression using four different dependent variables: The dependent variable in Panel A is the yearly gross-of-fees Carhart (1997) four-factor alpha. In Panel B, the dependent variable is the fund's unsystematic risk based on the Carhart (1997) four-factor model measured as in Table 6 . The dependent variable in Panel C (Panel D) is the yearly average style (performance) extremity as defined in Table 7 (Table 8). The main independent variables are the duality dummy and the interaction between the duality dummy and several governance factors. The duality dummy equals one if the fund's manager also serves as the chairman of the fund's board of directors and zero otherwise. \# IND is defined as the number of independent board directors for each fund in each year. Ownership IND is specified as the fund ownership of the fund's average independent director in a given year, divided by 1,000 USD. Other independent variables are defined in Tables 2 and 3. All regression specifications include time fixed effects and segment fixed effects. Robust pvalues of the regression coefficients in parentheses are based on standard errors clustered by fund. ***, **, and * denote statistical significance at the 1\%-, 5\%-, and 10\%-level, respectively.

Panel A: Performance

\begin{tabular}{lccc}
\hline Dependent variable: & \multicolumn{3}{c}{ Carhart Alpha } \\
\cline { 2 - 4 } Model: & $(1)$ & $(2)$ & $(3)$ \\
\hline Duality & $-0.0483^{* *}$ & $-0.0454^{* * *}$ & $-0.0619^{* * *}$ \\
& $(0.015)$ & $(0.001)$ & $(0.004)$ \\
Interaction: & & & \\
Duality* \# IND & $0.0082^{* *}$ & & 0.0063 \\
& $(0.047)$ & & $(0.152)$ \\
Duality*Ownership IND & & $0.0007^{* *}$ & $0.0006^{* *}$ \\
& & $(0.019)$ & $(0.048)$ \\
Governance factors: & & & 0.0015 \\
\# IND & 0.0014 & & $(0.166)$ \\
& $(0.175)$ & & -0.0001 \\
Ownership IND & & -0.0001 & $(0.669)$ \\
& & $(0.379)$ & Yes \\
Fund and manager characteristics & Yes & Yes & Yes \\
Segment fixed effects & Yes & Yes & Yes \\
Time fixed effects & Yes & Yes & 1,894 \\
Observations & 1,894 & 1,894 & $8.44 \%$ \\
$\mathrm{R}^{2}$ & $7.10 \%$ & $8.16 \%$ &
\end{tabular}


Table 9 - Continued

Panel B: Unsystematic Risk

\begin{tabular}{lccc}
\hline Dependent variable: & \multicolumn{3}{c}{ Carhart Unsystematic Risk } \\
\cline { 2 - 4 } Model: & $(1)$ & $(2)$ & $(3)$ \\
\hline Duality & $\left(0.0278^{* * *}\right.$ & $0.019)^{* * *}$ & $0.0319^{* * *}$ \\
Interaction: & & $(<0.001)$ & $(<0.001)$ \\
Duality* \# IND & $-0.0043^{* *}$ & & $-0.0040 * *$ \\
& $(0.014)$ & & $(0.017)$ \\
Duality*Ownership IND & & $-0.0002 * * *$ & $-0.0002 * *$ \\
& & $(0.004)$ & $(0.017)$ \\
Governance factors: & & & -0.0003 \\
\# IND & -0.0005 & & $(0.231)$ \\
& $(0.102)$ & & $0.0001 * *$ \\
Ownership IND & & $0.0001 * * *$ & $(0.014)$ \\
& & $(0.002)$ & Yes \\
Fund and manager characteristics & Yes & Yes & Yes \\
Segment fixed effects & Yes & Yes & Yes \\
Time fixed effects & Yes & Yes & 1,894 \\
Observations & 1,894 & 1,894 & $44.17 \%$ \\
$\mathrm{R}^{2}$ & $43.81 \%$ & $43.97 \%$ &
\end{tabular}

Panel C: Style Extremity

\begin{tabular}{lccc}
\hline Dependent variable: & \multicolumn{3}{c}{ Average Style Extremity } \\
\cline { 2 - 4 } Model: & $(1)$ & $(2)$ & $(3)$ \\
\hline Duality & $\left(0.6584^{* *}\right.$ & $0.5108^{* * *}$ & $0.7692^{* * *}$ \\
& & $(<0.001)$ & $(0.006)$ \\
Interaction: & $-0.1010^{*}$ & & -0.0889 \\
Duality* \# IND & $(0.074)$ & & $(0.101)$ \\
& & $-0.0060 * * *$ & $-0.0048 * *$ \\
Duality*Ownership IND & & $(0.006)$ & $(0.017)$ \\
& & & -0.0121 \\
Governance factors: & -0.0135 & & $(0.146)$ \\
\# IND & $(0.101)$ & & 0.0015 \\
& & $0.0020 * *$ & $(0.130)$ \\
Ownership IND & & $(0.044)$ & Yes \\
Fund and manager characteristics & Yes & Yes & Yes \\
Segment fixed effects & Yes & Yes & Yes \\
Time fixed effects & Yes & Yes & 1,894 \\
Observations & 1,894 & 1,894 & $10.84 \%$ \\
$\mathrm{R}^{2}$ & $10.53 \%$ & $10.10 \%$ & \\
\hline
\end{tabular}


Table 9 - Continued

Panel D: Performance Extremity

\begin{tabular}{lccc}
\hline Dependent variable: & \multicolumn{3}{c}{ Carhart Alpha Extremity } \\
\cline { 2 - 4 } Model: & $0.5071^{*}$ & $(2)$ & $(3)$ \\
\hline Duality & $(0.070)$ & $(<0.001)$ & $0.6511^{* *}$ \\
Interaction: & & & $(0.033)$ \\
Duality* \# IND & -0.0215 & & -0.0075 \\
& $(0.726)$ & & $(0.896)$ \\
Duality*Ownership IND & & $-0.0067 * *$ & $-0.0063 * *$ \\
& & $(0.034)$ & $(0.036)$ \\
Governance factors: & & & -0.0127 \\
\# IND & -0.0157 & & $(0.253)$ \\
& $(0.148)$ & & $0.0025 *$ \\
Ownership IND & & $0.0029 * *$ & $(0.093)$ \\
& & $(0.047)$ & Yes \\
Fund and manager characteristics & Yes & Yes & Yes \\
Segment fixed effects & Yes & Yes & Yes \\
Time fixed effects & Yes & Yes & 1,894 \\
\hline Observations & 1,894 & 1,894 & $10.80 \%$ \\
$\mathrm{R}^{2}$ & $10.56 \%$ & $10.82 \%$ &
\end{tabular}

